\title{
HAEMATOCOCCUS PLUVIALIS EXTRACT PROMOTING THE RECOVERY OF MEMORY IMPAIRMENT IN ALZHEIMER'S RATS: ANTI-INFLAMMATORY AND ANTIAPOPTOTIC EFFECTS
}

\author{
FAROUK K EL-BAZ ${ }^{*}$, HANAN F ALY ${ }^{2}$, WAGDY KB KHALIL ${ }^{3}$, GAMILA H ALI ${ }^{4}$, HODA F BOOLES ${ }^{3}$
}

${ }^{1}$ Department of Plant Biochemistry, National Research Centre, 33 El Bohouth Street (Former El Tahrir Street), Dokki, P.0.12622, Giza, Egypt. ${ }^{2}$ Department of Therapeutic Chemistry, National Research Centre, 33 El Bohouth Street (Former El Tahrir Street), Dokki, P.0.12622, Giza, Egypt. ${ }^{3}$ Department of Cell Biology, National Research Centre, 33 Bohouth Street (Former El Tahrir Street), Dokki, P.0.12622, Giza, Egypt. ${ }^{4}$ Department of Water Pollution Research, National Research Centre, 33 El Bohouth Street (Former El Tahrir Street), Dokki, P.0.12622, Giza, Egypt. Email: fa_elbaz@hotmail.com

Received: 15 August 2016, Revised and Accepted: 31 August 2016

\section{ABSTRACT}

Objective: The present study was conducted to investigate the role of Haematococcus pluvialis extract against oxidative damage, the inflammatory, and apoptotic impacts characterizing the neurodegenerative disorders.

Methods: Oxidative stress, B-cell lymphoma 2, brain-derived neurotrophic factor, the inflammation, apoptotic and antiapoptotic impacts in Alzheimer's disease (AD) rats were determined through assessment of glutathione reduced (GSH), GSH peroxidase (GPx), lipid peroxide (malondialdehyde), the cytokines level such as tumor necrosis factor-alpha (TNF- $\alpha$ ), interleukins (IL-6 and IL-1 $\beta$ ), and macrophage inflammation protein (MIP1 $\alpha$ ) in AD rats. Moreover, the expression of phosphoinositide 3-kinase (PI3K) and serine-threonine protein kinase (Akt) genes regulating the apoptosis in $\mathrm{AD}$ rats was measured.

Results: The results revealed that levels of TNF- $\alpha$, IL-6, IL-1 $\beta$, and MIP1 $\alpha$ were significantly increased in AD rats. Moreover, the expression of PI3K and Akt genes was downregulated which it was coincided with the increase of apoptosis in AD rats. On the other hand, treatment of AD rats with H. pluvialis extract decreased the oxidative stress of $\mathrm{AD}$ in the form of prevention the inflammatory and apoptotic impacts.

Conclusion: H. pluvialis could be used for ameliorating $\mathrm{AD}$ due to its role in decreases the oxidative stress of $\mathrm{AD}$ in the form of prevention the inflammatory and apoptotic impacts. H. pluvialis is a very attractive candidate for uses against neurodegenerative disorders that are caused by increases oxidative stress inducing neuroinflammation and apoptosis.

Keywords: Haematococcus pluvialis, Oxidative stress, Inflammation biomarkers, Apoptotic and antiapoptotic impacts.

(C) 2016 The Authors. Published by Innovare Academic Sciences Pvt Ltd. This is an open access article under the CC BY license (http://creativecommons, org/licenses/by/4. 0/) DOI: http://dx.doi.org/10.22159/ajpcr.2016.v9s3.14715

\section{INTRODUCTION}

It is well known that oxidative damage affects the central nervous system (CNS) and is significantly assumed to induct Alzheimer's pathogenesis [1]. The reasons of occurrence of these diseases because the brain of human is the target organ for the oxidative stress due to the following: (a) Increasing the oxygen utilization and enhancing the activity of the mitochondria in the nerve cells induces oxygen and nitrogen reactive species; (b) promoting the production of polyunsaturated fatty acids in the neural cells which are sensitive to oxidation; (c) increasing the reactive iron ions in several parts of the brain; (d) several neurotransmitters inter a cycle of auto-oxidation to produce neurotoxic components in the most of brain spaces [2] Moreover, it has been found that oxidative stress in neural cells-induced inflammation is considered as one of the most reasons to induce CNS diseases [3-5]. One of the main reasons of inducing oxidative stress in neural cells is Alzheimer as showed in several experiments on animal models and human patients [5].

Several experiments on the neurotrophic factor derived in the brain revealed that brain-derived neurotrophic factor (BDNF) is overexpressed in several regions of the brain such as hippocampus and cortex. Moreover, BDNF is the main neuromolecule in the brain, which acts an important role in the survival and differentiation of the neural cells $[6,7]$. Furthermore, several studies were conducted on the BDNFmutant mice which exhibited increase in the impairment rate of memory behavior and learning [8,9]. Furthermore, it has been found that BDNF was able to decline the apoptosis rate in several brain regions, which is associated with enhancement the survival of neural cells without the presence of growth promoters [10]. In contrary, absence or decrease the level of BDNF is associated with increase the rate of apoptosis in the brain tissues. Moreover, increase the level of BDNF mRNA is coincided with increase the B-cell lymphoma $2(\mathrm{Bcl}-2)$ protein levels which are considered as antiapoptotic and protective protein for neural cells [10].

Recent research on Alzheimer demonstrated that occurring oxidative stress in the mitochondria is associated with high incidence of Alzheimer's disease (AD) [11]. There are several pathways are responsible for the survival of the cells and act an important role in the induction of the oxidation stress in $\mathrm{AD}$ [12]. It has been found that phosphoinositide 3-kinase (PI3K)/Akt pathway is one of the most important pathways in this fact. The research on the PI3K/Akt pathway revealed that increase the concentration of amyloid beta protein in the brain cells of $\mathrm{AD}$ might be suppressing the PI3K/Akt pathway through decrease the PI3K and Akt activities $[13,14]$. Moreover, Akt in normal case is highly expressed in the brain cells and act as regulator of PI3K. In the same time, Akt is acting in several cases as enhancer for increase the phosphorylation in neural cells inducing apoptosis [15-17]. The apoptotic pathway by Akt signaling is attributed to regulation the expression of apoptotic-related genes such as Bcl-2 [18-20].

On the other hand, astaxanthin (ASTA) $\left(3,3^{\prime}\right.$-dihydroxy- $\beta$ - $\beta^{\prime}$-carotene$4,4^{\prime}$-dione) presents in the natural extract from $H$. pluvialis which considered a powerful antioxidant and a good candidate for the prevention of intracellular oxidative stress. Antioxidant molecules, especially carotenoids, play an important role in controlling oxidative process. These antioxidant molecules (carotenoids) possess a strong antioxidant power due to their double-bonded structure, allowing the delocalization of impaired electrons [21]. There is a growing interest 
in from the carotenoids' family. It is a xanthophyll, meaning that, unlike $\beta$-carotene and lycopene, it is a polar molecule that is able to scavenge free oxygen radicals. The polyene chain in ASTA crosses the cell membrane, allowing the polar ends of the molecule to be exposed to the cytoplasm and external sides of the cell in the meantime $[22,23]$. This disposition facilitates the electron transfer from the cytoplasm to the outer part of the cell. The terminal ring of the ASTA seems to be the final scavenger of the reactive oxygen species (ROS). The ASTA by its provision could also have a synergistic effect with vitamin $C$ that would recharge ASTA once it has scavenged ROS [24].

Therefore, the objective of this study was to investigate the impact of $H$. pluvialis extract against oxidative stress inducing inflammation. Moreover, the effect of $H$. pluvialis extract on the biological pathway regulating the apoptosis in AD rats was also studied.

\section{MATERIALS AND METHODS}

\section{Chemicals}

Donepezil, reagents, and kits were purchased from the Sigma Chemical Company (USA), whereas aluminum chloride $\left(\mathrm{AlCl}_{3}\right)$ was purchased from $\mathrm{CDH}$, India. TRIzol reagent was bought from Invitrogen (Germany). The reverse transcription and polymerase chain reaction (PCR) kits were obtained from Fermentas (USA). SYBR Green Mix was purchased from Stratagene (USA).

\section{Cultivation of $\boldsymbol{H}$. pluvialis}

H. pluvialis (strain No. CCAP 34/7) was isolated by spreading $0.1 \mathrm{ml}$ of water samples collected from Nile River phytoplankton using BG11 media for algal isolation into Petri dishes containing 1.5\% agar for solidification [25]. Single colonies of algae were then recultivated in the specified liquid media as non-axenic batch cultures $(50 \mathrm{ml})$ at $25 \pm 2^{\circ} \mathrm{C}$ and $24 \mathrm{hrs}$ with continuous white fluorescent lamp intensity $\approx 2500$ Lux. Cultivation was carried on an open pond with a capacity of $70 \mathrm{~L}$ containing $55 \mathrm{~L}$ of growth media. After cultivation, the biomass was initially separated from the water by gravitational settling and was then further concentrated by centrifugation, dried at $40^{\circ} \mathrm{C}$ and grounded into homogeneous fine powder.

\section{Preparation of $H$. pluvialis ethanolic extract}

H. pluvialis powder $(100 \mathrm{~g})$ was soaked in ethanol $(80 \%)$ and shacked on shaker (Heidolph UNIMAX 2010) for $48 \mathrm{hrs}$ at $150 \mathrm{rpm}$. The extract was filtered using a Buchner funnel and Whatman No. 4 filter paper, and the algal residue was reextracted with the addition of fresh ethanol for another 2 times. Combined filtrates were concentrated using rotary evaporator (Heidolph-Germany) at $40^{\circ} \mathrm{C}$ under vacuum to dryness. The dry extract was stored at $-20^{\circ} \mathrm{C}$ in a freeze and kept for further analysis [26].

\section{Experiment}

Animals

Male Wistar albino rats (180-200 g) procured from Central Animal House, National Research Centre (NRC) were used. Animals were acclimatized to the laboratory conditions at room temperature before the experimentation. Animals were kept under standard conditions of a $12 \mathrm{hrs}$ light/dark cycle with food and water in plastic cages with soft bedding. The protocol was approved by the NRC Ethics Committee Guidelines (Approval No.: 0111457) for the use and care of animals, provided that the animals will not suffer at any stage of the experiment.

\section{Drug and treatment schedule}

$\mathrm{AlCl}_{3}$ solutions were made freshly at the beginning of each experiment. For oral administration, $\mathrm{AlCl}_{3}$ was dissolved in drinking water and administered in a dose of $100 \mathrm{mg} / \mathrm{kg}$, p.o. to rats daily for 6 weeks $0.5 \mathrm{ml} / 100 \mathrm{~g}$ b.wt. [27]. Donepezil drug was daily administrated for 1 month in a dose $10 \mathrm{mg} / \mathrm{kg}$ b.wt. [28].

Animals were randomized into five groups of 10 rats each adult male Wistar rats based on their body weight. Each group had 10 numbers of animals. The groups were as follows:
- $\quad$ Group 1: Normal healthy untreated control rats

- Group 2: Normal control rats treated with H. pluvialis ethanolic extract

- Group 3: Serving as AD rats, where rats were orally administered with $\mathrm{AlCl}_{3}$

- Group 4: AD rats treated orally daily with $H$. pluvialis ethanolic extract for 4 weeks in a dose of $150 \mathrm{mg} / \mathrm{kg}$ b.wt. [29]

- Group 5: AD rats orally treated daily for 4 weeks with donepezil standard drug.

\section{Brain tissue sampling and preparation}

At the end of the experiment, the rats were fasted overnight, subjected to anesthesia with diethyl ether and sacrificed. The whole brain of each rat was rapidly dissected, washed with isotonic saline, and dried on filter paper. The brain was weighed and homogenized in ice-cold medium containing $50 \mathrm{mM}$ Tris/ $\mathrm{HCl}$ and $300 \mathrm{mM}$ sucrose at $\mathrm{pH} 7.4$ to give a $10 \%(\mathrm{w} / \mathrm{v})$ homogenate [30]. This homogenate was centrifuged at $1400 \times g$ for 10 minutes at $4^{\circ} \mathrm{C}$. The supernatant was stored at $-80^{\circ} \mathrm{C}$ and used for biochemical analyses that included oxidative stress biomarker non-enzymatic glutathione (GSH) level, GSH peroxidase (GPx) and malondialdehyde (MDA) activity, antiapoptotic markers Bcl-2, and BDNF levels. The ethical conditions were applied such that the animals suffered no pain at any stage of the experiment, and the study was approved by the Ethics Committee of the NRC. Animals were disposed of in bags provided by the Committee of Safety and Environmental Health, NRC.

\section{Biochemical analyses}

Brain GSH was measured colorimetrically according to the method of Moron et al. [31]; GPx was determined colorimetrically according to the method of Ozdemir et al. [32]. Lipid peroxidation products represented by MDA were evaluated by the method of Satoh [33].

Brain Bcl-2 was detected by enzyme-linked immunosorbent assay (ELISA) technique according to the method of Barbareschi et al. [34]. Brain BDNF was detected by ELISA technique according to the method of Barakat-Walter [35].

\section{Cytokines determination}

Cytokine concentrations were measured in the brain tissues of male rats to monitor the baseline inflammatory scenario upon supplementation. Levels of tumor necrosis factor-alpha (TNF- $\alpha$ ), interleukin 6 (IL-6), IL$1 \beta$, and macrophage inflammation protein (MIP1 $\alpha$ ) were determined by ELISA, according to the manufacturer's instructions (Duo Set Kit: Quantikine, R\&D System, Minneapolis, MN, USA).

\section{Apoptosis assay}

The brain tissue (100 mg per sample) was made into single-cell suspensions according to method of Villalba et al. [36]. Cells apoptosis was determined by flow cytometry (FCM) assay using Annexin V/PI apoptosis detection kit. The single-cell suspension $\left(1 \times 10^{6}\right.$ cells $\left./ \mathrm{ml}\right)$ was suspended in $200 \mu \mathrm{l}$ ice-cold binding buffer, and then, $10 \mu \mathrm{l}$ horseradish peroxidase fluorescein isothiocyanate (FITC) labeled Annexin V, and $5 \mu \mathrm{l}$ propidium iodide (PI) was added. The cell suspension was incubated in darkness at room temperature for 15 minutes. Apoptosis rate was determined by FCM. In this study, both FITC and PI-negative cells were considered as normal cells. FITC-single positive and PI-negative cells were defined as early apoptotic cells, whereas both FITC and PI-positive cells were considered as late apoptotic or necrosis cells.

\section{Gene expression analysis}

\section{Extraction of total RNA and cDNA synthesis}

Brain tissues of male rats were used to extract the total RNA using TRIzol ${ }^{\circledR}$ Reagent (Invitrogen, Germany) kit. The isolation method was carried out according to the manufacturer's instructions of the above kit. Approximately, $50 \mathrm{mg}$ of the brain tissues were mixed with some drops of liquid nitrogen and homogenized in $1 \mathrm{ml}$ of TRIzol ${ }^{\circledR}$ reagent in autoclaved mortar. Afterward, total RNA was dissolved and preserved in diethylpyrocarbonate-treated water up to use. 
To assess the RNA yield and purity of the total RNA, RNAse-free DNAse I (Invitrogen, Germany) was used to digest DNA contamination. A small drop of isolated RNA was examined photospectrometrically at $260 \mathrm{~nm}$. The purity of total RNA was determined between 1.8 and 2.1 to be good purified when it examined by photospectrometer at the $260 / 280 \mathrm{~nm}$ ratio. To avoid RNA damaging, aliquots of RNA were prepared after isolation for either reverse transcription reaction or otherwise for storing at $-80^{\circ} \mathrm{C}$ up to use.

To synthesize, the complementary DNA (cDNA) isolated RNA from brain tissues was reverse transcribed into cDNA. The reaction volume was carried out in $20 \mu \mathrm{l}$. The reaction volume was prepared according to the instructions of the RevertAidTM First Strand cDNA Synthesis Kit (MBI Fermentas, Germany). The reverse transcription (RT) reaction was performed for 10 minutes at $25^{\circ} \mathrm{C}$. Afterward, the tubes of the reaction were put in thermocycler machine for 60 minutes at $42^{\circ} \mathrm{C}$ and then, the reaction was terminated for 5 minutes at $99^{\circ} \mathrm{C}$. The PCR products containing the cDNA were kept at $-20^{\circ} \mathrm{C}$ up to use for DNA amplification $[37,38]$.

\section{Quantitative real-time PCR (qRT-PCR)}

A step one real-time PCR System (Applied Biosystem, USA) was used to assess the copy of the cDNA of male rats to detect the expression values of the tested genes. To perform the PCR reaction, a volume of $25 \mu \mathrm{ml}$ of reaction mixtures was prepared containing $12.5 \mu \mathrm{ml}$ of $\mathrm{SYBR}^{\circledR}$ green (TaKaRa, Biotech Co., Ltd.), $0.5 \mu \mathrm{ml}$ of $0.2 \mu \mathrm{mM}$ forward and reverse primers, $6.5 \mu \mathrm{ml}$ DNA-RNA free water, and $2.5 \mu \mathrm{ml}$ of the synthesized cDNA. The cDNA was propagated using reaction program consisted of three steps. In the first step, the PCR tubes were incubated at $95^{\circ} \mathrm{C}$ for 3 minutes. In the second step, the reaction program consisted of 50 cycles. Each cycle of them consisted of three substeps: (a) 15 seconds at $95^{\circ} \mathrm{C}$; (b) 30 seconds at $60^{\circ} \mathrm{C}$; (c) 30 seconds at $72^{\circ} \mathrm{C}$. In the third step, the reaction program consisted of 71 cycles. The first cycle of them started at $60^{\circ} \mathrm{C}$ for 10 seconds, and then, the followed cycles increased about $0.5^{\circ} \mathrm{C}$ every 10 seconds up to $95^{\circ} \mathrm{C}$. A melting curve of the reaction was performed for each qRT-PCR termination at $95^{\circ} \mathrm{C}$ to assess the quality of the primers. To verify that the reaction of the qRT-PCR does not have any contamination PCR tubes containing non-template control were used. The sequences of the specific primer of the genes used are listed in Table 1. The relative quantification of the target genes to the reference ( $\beta$-actin) was determined using the $2-\Delta \Delta \mathrm{CT}$ method.

\section{Statistical analysis}

Data were analyzed by one-way analysis of variance using the Statistical Package for the Social Sciences program, version 11 followed by least significant difference to compare significance between groups $(p \leq 0.05)$ coupled with Co-state computer program, where unshared letters are significant at $\mathrm{p} \leq 0.05$

\section{Calculations:}

$\%$ Change to control $=\frac{\text { Mean of control }- \text { Mean of treated }}{\text { Mean of control }}$

$\%$ of improvement $=\frac{\text { Mean of disease }- \text { Mean of treated }}{\text { Mean of control }} \times 100$

Table 1: Primer sequences used for qPCR

\begin{tabular}{lll}
\hline Gene & Primer sequence (5'-3') & References \\
\hline PI3K & F: AGCTGGTCTTCGTTTCCTGA & Li et al. [39] \\
& R: GAAACTTTTCCCACCACGA & \\
Akt & F: ACTCATTCCAGACCCACGAC & \\
& R: CCGGTACACCACGTTCTT & \\
$\beta$-actin & F: CAC GTG GGC CGC TCT AGG CAC CAA & Khalil and Booles \\
& & {$[37]$} \\
& R: CTC TTT GAT GTC ACG CAC GAT TTC & \\
\hline
\end{tabular}

F: Forward primer, R: Reverse primer, PI3K: Phosphati-dylinositol-3 kinase, Akt: Serine/threonine protein kinase B, qPCR: Quantitative polymerase chain reaction

\section{RESULTS AND DISCUSSION}

Effect of $\boldsymbol{H}$. pluvialis extract on the oxidative stress biomarkers

Table 2 demonstrated an insignificant change in GSH and GPx and MDA levels in normal control rats treated with $H$. pluvialis extract comparing with untreated normal control rats. A significant reduction was detected in GSH level and GPx activity in AD rats as compared to normal control rats with percentages $68.48 \%$ and $64.10 \%$, respectively. However, a significant increase in MDA level was noticed in AD-induced rats (242.10\%). H. pluvialis extract-treated AD rats exhibited noticeable amelioration in GSH level and GPx activity with improvement percentages $52.46 \%$ and $29.49 \%$, respectively. However, the percentages of improvement in GSH level and GPx enzyme activity reached to $53.48 \%$ and $42.94 \%$, respectively, upon using donepezil reference drug. The data manipulated also in Table 2 indicated the treatment of $\mathrm{AD}$ rats with $\mathrm{H}$. pluvialis extract significantly ameliorated MDA level with the percentage of improvement $154.86 \%$ comparing with $202.63 \%$, for standard drug.

Indeed, most of the neurodegenerative disorders such as AD are marked by neuroinflammation due to increase the oxidized proteins and lipids as well as alteration in the free radical species in either animal or human [40]. The present results revealed a significant reduction in GSH level and GPx activity, beside the significant increase in MDA level in AD rats. Al has neurotoxic effect by many mechanisms such as induction of oxidative damage, enhancing the plaques building, and aggregation which induce degeneration and death of the neural cells. Oxidative injury in AD-induced rats is mainly attributed to weakness of the body defense due to decrease in the antioxidant levels which enhance the oxidative stress induction including high lipid peroxidation, depletion of brain GSH, and inhibition of GPx which may be related to increase $\mathrm{H}_{2} \mathrm{O}_{2}$ cytotoxicity in endothelial cells as a leading cause of GSH reductase inhibition $[41,42]$. It has been found that exposure to $\mathrm{Al}$ or its derivatives is able to increase the free radicals generation and decrease the activity level of antioxidant enzymes such as SOD, GSH, and GPx [43].

Effect of $\boldsymbol{H}$. pluvialis extract on the brain Bcl-2 and BDNF levels

The data tabulated in Table 3 indicated an insignificant change in brain Bcl-2 and BDNF levels of normal control rats treated with $H$. pluvialis extract comparing with normal untreated rats. AD-induced rats showed a significant decrease in Bcl-2 (55.65\%) and BDNF $(46.85 \%)$ as compared to normal control rats. Remediation of AD rats with H. pluvialis extract showed improvement percentages in Bcl-2 and BDNF reached to $31.11 \%$ and $31.18 \%$, respectively, comparing with $46.51 \%$ and $35.87 \%$, respectively, upon using donepezil standard drug.

Regarding the antiapoptotic marker, the current results showed that the levels of both Bcl-2 and BDNF decreased significantlyin the brain of AD rats. The results demonstrated that BDNF could be considered as potentially protective signal and reenhance the antioxidant defenses of the AD rats to the normal case. In addition, BDNF might be considered as suppressor for the DNA damage and apoptosis as well as in the prevention and/or reversal of Alzheimer's and other neurological diseases [43]. Moreover, the alteration in several biological parameters such as inflammatory (Nuclear factor- $\kappa \mathrm{B} / \mathrm{Ikb}-\beta$ ) and apoptotic (Bcl-2/Bax) pathway as well as with the expression of pancreatic and duodenal homeobox genes in coinciding with the BDNF and PI3k-Akt could be competent to exhibit cytoprotective impact toward several toxic chemicals [43]. Aly et al. [42] suggested that $\mathrm{Al}$ as oxidative stress producer is able to disrupt the balance between neurotrophin and the proinflammatory cytokine and thus lead to induce several CNS diseases. In addition, Al decreases the levels of $\mathrm{Bcl}-2$ and changes the ratio of $\mathrm{Bax} / \mathrm{Bcl}-2$ ratio, in which it plays an important role in the induction of apoptosis and generation of cytochrome P450 and activates the caspase-3 $[27,44]$.

Effect of $H$. pluvialis extract on the cytokines level

Effect of $H$. pluvialis extract on the inflammatory parameters such as IL- 6 and IL- $1 \beta$, MIP1 $\alpha$, and TNF- $\alpha$ is summarized in Table 4. The results revealed that levels of TNF- $\alpha$, IL-6, IL-1 $\beta$, and MIP1 $\alpha$ 
Table 2: GSH, GPx and MDA levels in brain tissue of AD induced rats supplemented with $H$. pluvialis extract

\begin{tabular}{llll}
\hline Groups/parameters & GSH (U/mg protein) & GPX (U/mg protein) & MDA (nmol/mg protein) \\
\hline Normal control rats & $39.06 \pm 2.20^{\mathrm{a}}$ & $1.56 \pm 0.01^{\mathrm{a}}$ & $7.60 \pm 0.60^{\mathrm{a}}$ \\
Normal control rats+H. pluvialis extract & $42.13 \pm 2.23^{\mathrm{a}}$ & $1.55 \pm 0.19^{\mathrm{a}}$ & $6.60 \pm 0.30^{\mathrm{a}}$ \\
\% Change to control & 7.86 & 0.64 & 13.16 \\
AD rats & $12.31 \pm 1.12^{\mathrm{b}}$ & $0.56 \pm 0.03^{\mathrm{b}}$ & $26.00 \pm 2.12^{\mathrm{b}}$ \\
\% Change to control & 68.48 & 64.10 & 242.10 \\
AD rats+H. pluvialis extract & $32.80 \pm 2.23^{\mathrm{c}}$ & $1.02 \pm 0.20^{\mathrm{c}}$ & $14.23 \pm 1.00^{\mathrm{c}}$ \\
\% Change to control & 16.59 & 34.62 & 87.23 \\
\% of improvement & 52.46 & 29.49 & 154.86 \\
AD rats+standard drug & $33.20 \pm 3.00^{\mathrm{c}}$ & $1.23 \pm 0.07^{\mathrm{c}}$ & $10.60 \pm 2.20^{\mathrm{c}}$ \\
\% Change to control & 15.00 & 21.15 & 39.47 \\
\% of improvement & 53.48 & 42.94 & 202.63 \\
\hline
\end{tabular}

Data are means \pm SD of 10 rats in each group. Unshared letters between groups are the significance value at $\mathrm{p} \leq 0.05$. SD: Standard deviation, AD: Alzheimer's disease,

H. pluvialis: Haematococcus pluvialis, GSH: Glutathione, GPx: Glutathione peroxidase, MDA: Malondialdehyde

Table 3: Bcl-2 and BDNF levels in brain tissue of AD induced rats supplemented with $H$. pluvialis extract

\begin{tabular}{lll}
\hline Groups/parameters & Bcl-2 (pg/mg protein) & BDNF (pg/mg protein ) \\
\hline Normal control rats & $120.07 \pm 6.50^{\mathrm{a}}$ & $90.12 \pm 7.00^{\mathrm{a}}$ \\
Normal control rats+H. pluvialis extract & $122.10 \pm 4.20^{\mathrm{a}}$ & $89.10 \pm 3.29^{\mathrm{a}}$ \\
\% Change to control & 1.69 & 1.12 \\
AD rats & $53.25 \pm 4.10^{\mathrm{b}}$ & $47.90 \pm 1.20^{\mathrm{b}}$ \\
\% Change to control & 55.65 & 46.85 \\
AD rats+H. pluvialis extract & $90.60 \pm 8.22^{\mathrm{c}}$ & $76.00 \pm 3.98^{\mathrm{c}}$ \\
\% Change to control & 24.54 & 15.67 \\
\% of improvement & 31.11 & 31.18 \\
AD rats+standard drug & $109.10 \pm 6.50^{\mathrm{c}}$ & $80.23 \pm 3.21^{\mathrm{c}}$ \\
\% Change to control & 9.14 & 10.94 \\
\% of improvement & 46.51 & 35.87 \\
\hline
\end{tabular}

Data are means \pm SD of 10 rats in each group. Unshared letters between groups are the significance value at $\mathrm{p} \leq 0.05$. AD: Alzheimer's disease, H. pluvialis: Haematococcus pluvialis, Bcl-2: B-cell lymphoma 2, BDNF: Brain derived neurotrophic factor, SD: Standard deviation

Table 4: Inflammatory cytokines level in brain tissue of AD induced rats supplemented with $H$. pluvialis extract

\begin{tabular}{|c|c|c|c|c|}
\hline Groups/parameters & TNF- $\alpha$ (ng/mg protein) & IL-6 (ng/mg protein) & IL-1ß (ng/mg protein) & MIP1a (ng/mg protein) \\
\hline Normal control rats & $17.4 \pm 6.2^{c}$ & $1.8 \pm 0.82^{c}$ & $1.4 \pm 0.51^{c}$ & $16.4 \pm 3.7^{c}$ \\
\hline Normal control rats $+H$. pluvialis & $16.90 \pm 7.8^{\mathrm{c}}$ & $1.9 \pm 0.60^{c}$ & $1.33 \pm 0.42^{\mathrm{c}}$ & $17.20 \pm 2.7^{\mathrm{c}}$ \\
\hline extract & 2.87 & 5.55 & 5.00 & 4.87 \\
\hline \multicolumn{5}{|l|}{$\%$ Change to control } \\
\hline $\mathrm{AD}$ rats & $39.6 \pm 8.5^{\mathrm{a}}$ & $5.7 \pm 1.3^{\mathrm{a}}$ & $4.8 \pm 0.93^{\mathrm{a}}$ & $43.1 \pm 8.6^{\mathrm{a}}$ \\
\hline$\%$ Change to control & 127.58 & 216.66 & 242.85 & 162.80 \\
\hline $\mathrm{AD}$ rats $+H$. pluvialis extract & $20.2 \pm 5.3^{\mathrm{bc}}$ & $2.4 \pm 0.76^{\mathrm{bc}}$ & $1.9 \pm 0.62^{\mathrm{bc}}$ & $18.7 \pm 4.2^{\mathrm{bc}}$ \\
\hline$\%$ Change to control & 16.09 & 33.33 & 35.71 & 14.02 \\
\hline$\%$ of improvement & 111.49 & 183.33 & 207.14 & 148.78 \\
\hline AD rats+standard drug & $22.7 \pm 5.8^{\mathrm{b}}$ & $2.9 \pm 0.942^{b}$ & $2.3 \pm 0.54^{\mathrm{b}}$ & $21.3 \pm 5.3^{\mathrm{b}}$ \\
\hline$\%$ Change to control & 30.45 & 61.11 & 64.28 & 29.87 \\
\hline$\%$ of improvement & 97.12 & 155.55 & 178.57 & 132.92 \\
\hline
\end{tabular}

Data are means \pm SD of 10 rats in each group. Unshared letters between groups are the significance value at $\mathrm{p} \leq 0.05$. TNF- $\alpha$ : Tumor necrosis factor-alpha, IL: Interleukins MIP1: Macrophage inflammation protein, SD: Standard deviation

significantly increased in brain tissues of $\mathrm{AD}$ rats with percentages change $127.58 \%, 216.66 \%, 242.85 \%$, and $162.80 \%$, respectively, compared with those in control rats. However, the levels of the same parameters in brain tissues of AD rats treated with H. pluvialis extract decreased significantly with percentages of improvement $148.78 \%$, $111.49 \%, 183.33 \%$, and $207.14 \%$, respectively. In addition, the levels of MIP1 $\alpha$, TNF- $\alpha$, IL- 6 , and IL- $1 \beta$ decreased significantly in AD rats treated with the reference drug for $\mathrm{AD}$ treatment, compared with those in $\mathrm{AD}$ rats.

The current results exhibited high levels of inflammation markers such as TNF- $\alpha$, IL-6, IL-1 $\beta$, and MIP1 $\alpha$. Therefore, the increase in the inflammation markers might be enhanced by increasing the levels of the free radicals in the brain cells. It has been reported that CNS and brain cells are most sensitive cells to oxidative stress because their cell organelles and lipid/fatty acid exposed to high oxygen concentration inducing free radicals and lipid peroxidation [45]. These biological actions explain the mechanism of neurodegenerative diseases induction including Alzheimer which they are markedly coincided with oxidative stress causing DNA damage and decrease in the protection capability of neural cells against endogenous oxidation [45].

In contrary, treatment of AD rats with $H$. pluvialis extract significantly decreased the levels of the inflammation markers. Several reports suggested that the efficiency of $H$. pluvialis extract in protecting the inflammation in brain cells is attributed to the antioxidant carotenoid ASTA which is existed in H. pluvialis [46]. In the same line, it has been found that ASTA promoted anti-inflammatory effect by inhibiting the mitochondrial $\beta$-oxidation and suppressing the free radicals generation [47]. 
ASTA, a red-orange carotenoid originates the red of microalgae and other sea organisms, exhibits antioxidant, anti-inflammatory, and antiapoptotic effects [48]. Recently, ASTA was observed to protect neurons in laboratory experiments against chronic and acute neurodegenerative dysfunction, neurological disorders and was proposed as a beneficial strategy to treat neurological diseases [49]. Although other antioxidants, such as resveratrol have been shown to protect neurons from injury in similar model systems, ASTA presents many advantages compared to other antioxidants displaying protective effects [50].

In addition, ASTA was observed to stimulate the antioxidant enzymes such SOD and CAT activities [51]. Moreover, other studies reported that ASTA was able to protect the cells toward the mutagen carbon tetrachloride, and consequently, inhibit the hepatic damage through suppression the peroxidation of the lipids and enhancing the antioxidants production as well as regulating the process of the inflammation [52].

\section{Effect of $H$. pluvialis extract on the apoptosis rate}

Fig. 1 showed the effect of $H$. pluvialis extract on the apoptosis rate in brain tissues of male rats with $\mathrm{AD}$. The results showed that $\mathrm{AD}$ rats exhibited a high rate of apoptosis significantly compared with those of control group. However, the treatment of AD rats with $H$. pluvialis extract significantly decreased the rate of apoptosis compared with that in $\mathrm{AD}$ rats. Moreover, the rate of apoptosis significantly decreased in $\mathrm{AD}$ rats treated with donepezil drug compared with those in $\mathrm{AD}$ group.

Effect of the H. pluvialis extract on the expression of PI3K and Akt genes

The expression levels of the PI3K and Akt genes encoding phosphatidylinositol-3 kinase and serine/threonine protein kinase B, respectively, which play an important role in inhibiting the oxidative stress in the cells, were measured using quantitative real-time RT-PCR (Figs. 2 and 3). The results showed that $A D$ rats exhibited lower expression significantly levels of PI3K and Akt genes than those in control rats. However, the expression levels of PI3K and Akt genes were highly expressed in AD rats treated with $H$. pluvialis extract compared with those in AD rats. Moreover, the PI3K and Akt genes were upregulated in AD rats treated with donepezil drug compared with those in $\mathrm{AD}$ group.

The results indicated that the expression of PI3K and Akt genes was downregulated which it was coincided with increase the apoptosis in $\mathrm{AD}$ rats. However, treatment of $\mathrm{AD}$ rats with $H$. pluvialis extract upregulated the expression of PI3K and Akt genes which consequently decreased the rate of apoptosis and oxidative stress of AD. In agreement with the current observation, ASTA was found to inhibit the apoptosis process, decrease the dysfunction of the mitochondria and suppress the production of the intracellular free radicals in the in vitro cultured [53]. Moreover, it has been found that ASTA supplementation improved the function of the mitochondria in the white blood cells of either young or old dogs through regulating the ATP synthesis and enhancing the antioxidants activity [54].

\section{CONCLUSION}

H. pluvialis could be used for AD treatment due to it decreases oxidative stress in the form of prevention the inflammatory and apoptotic impacts. The biological activity of $H$. pluvialis extract is might be regulated by ASTA which is a potent antioxidant protecting the brain cells from the oxidative stress in $\mathrm{AD}$ rats. H. pluvialis is a very attractive candidate against certain neurodegenerative diseases that are caused by oxidative stress inducing neuroinflammation and apoptosis.

\section{ACKNOWLEDGMENT}

This work was supported and funded by the project entitled "Biodiesel production from algae as a renewable energy source." Funding Organization: Research Development and Innovation Program, Funding Program: EU-Egypt Innovation Fund, 2014-2016.

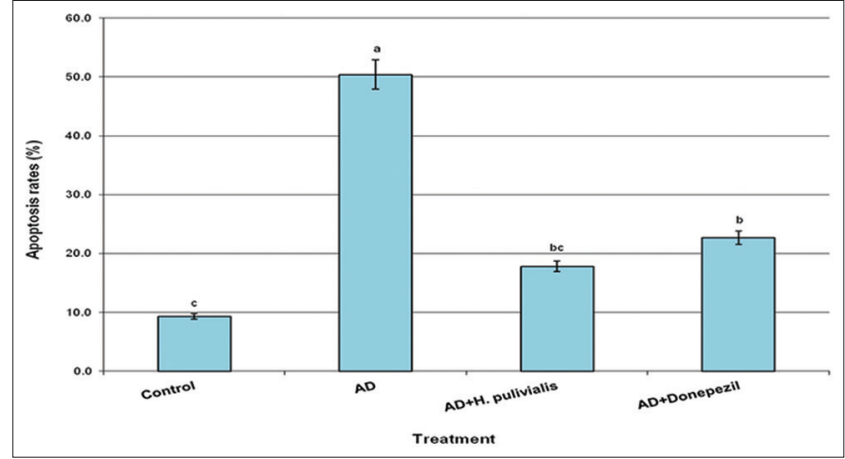

Fig. 1: Alterations of the apoptosis rate in brain tissues of Alzheimer's disease-rats supplemented with Haematococcus pluvialis extract. Data are presented as mean \pm standard error of mean. ${ }^{a, b, c}$ Followed by different superscripts are significantly different $(p \leq 0.05)$

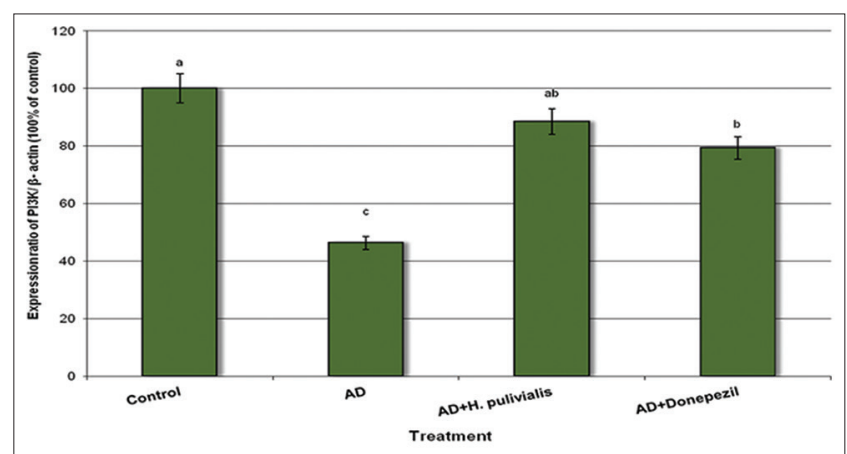

Fig. 2: Expression levels of phosphoinositide 3-kinase gene in brain tissues of Alzheimer's disease-induced rats treated with Haematococcus pluvialis extract. Data are presented as mean \pm standard error of mean. ${ }^{\mathrm{a}, \mathrm{b}, \mathrm{c}}$ Followed by different superscripts are significantly different $(p \leq 0.05)$

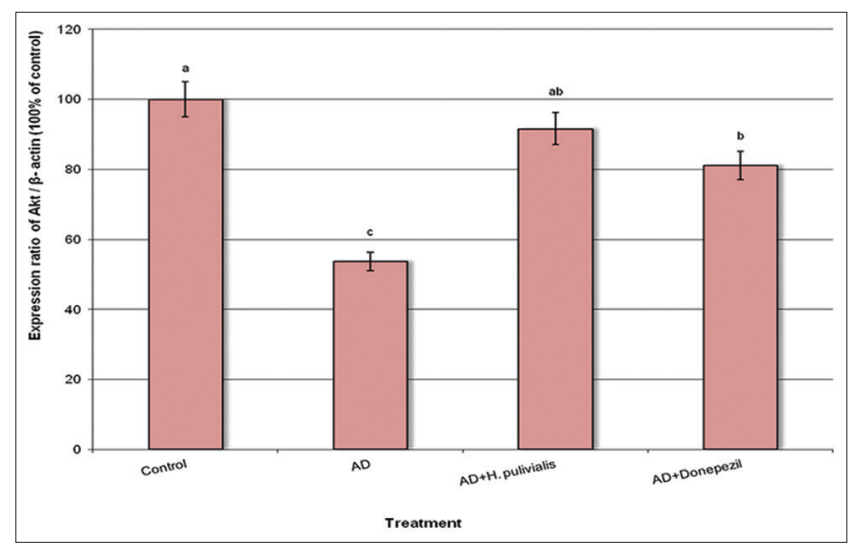

Fig. 3: Expression levels of Akt gene in brain tissues of Alzheimer's disease-induced rats treated with Haematococcus pluvialis extract. Data are presented as mean \pm standard error of mean. ${ }^{a, b, c}$ Followed by different superscripts are significantly different ( $p \leq 0.05)$

\section{REFERENCES}

1. Kaur K, Kaur R, Kaur M. Recent advances in Alzheimer's disease: Causes and treatment. Int J Pharm Pharm Sci 2016;8(2):8-15.

2. Choi BH. Oxygen, antioxidants and brain dysfunction. Yonsei Med J 1993;34(1):1-10.

3. Butterfield DA, Bader Lange ML, Sultana R. Involvements of the lipid 
peroxidation product, $\mathrm{HNE}$, in the pathogenesis and progression of Alzheimer's disease. Biochim Biophys Acta 2010;1801(8):924-9.

4. Whitton PS. Inflammation as a causative factor in the aetiology of Parkinson's disease. Br J Pharmacol 2007;150(8):963-76.

5. Qian L, Flood PM, Hong JS. Neuroinflammation is a key player in Parkinson's disease and a prime target for therapy. J Neural Transm (Vienna) 2010;117(8):971-9.

6. Post RM. Role of BDNF in bipolar and unipolar disorder: Clinical and theoretical implications. J Psychiatr Res 2007;41:979-90.

7. Pang PT, Teng HK, Zaitsev E, Woo NT, Sakata K, Zhen S, et al. Cleavage of proBDNF by tPA/plasmin is essential for long-term hippocampal plasticity. Science 2004;306(5695):487-91

8. Heldt SA, Stanek L, Chhatwal JP, Ressler KJ. Hippocampus-specific deletion of BDNF in adult mice impairs spatial memory and extinction of aversive memories. Mol Psychiatry 2007;12(7):656-70.

9. Gorski JA, Balogh SA, Wehner JM, Jones KR. Learning deficits in forebrain-restricted brain-derived neurotrophic factor mutant mice. Neuroscience 2003;121(2):341-54.

10. Fan M, Jin W, Zhao H, Xiao Y, Jia Y, Yin Y, et al. Lithium chloride administration prevents spatial learning and memory impairment in repeated cerebral ischemia-reperfusion mice by depressing apoptosis and increasing BDNF expression in hippocampus. Behav Brain Res 2015;291:399-406.

11. Aliev G, Priyadarshini M, Reddy VP, Grieg NH, Kaminsky Y, Cacabelos $\mathrm{R}$, et al. Oxidative stress mediated mitochondrial and vascular lesions as markers in the pathogenesis of Alzheimer disease. Curr Med Chem 2014;21(19):2208-17.

12. Ng TB, Wang H. Panaxagin, a new protein from Chinese ginseng possesses anti-fungal, anti-viral, translation-inhibiting and ribonuclease activities. Life Sci 2001;68(7):739-49

13. Kashour T, Burton T, Dibrov A, Amara FM. Late Simian virus 40 transcription factor is a target of the phosphoinositide 3-kinase/Akt pathway in anti-apoptotic Alzheimer's amyloid precursor protein signaling. Biochem J 2003;370:1063-75.

14. Ryder J, Su Y, Ni B. Akt/GSK3beta serine/threonine kinases: Evidence for a signalling pathway mediated by familial Alzheimer's disease mutations. Cell Signal 2004;16(2):187-200.

15. Brazil DP, Park J, Hemmings BA. PKB binding proteins. Getting in on the Akt. Cell 2002;111(3):293-303.

16. Gardai SJ, Hildeman DA, Frankel SK, Whitlock BB, Frasch SC, Borregaard $\mathrm{N}$, et al. Phosphorylation of Bax Ser184 by Akt regulates its activity and apoptosis in neutrophils. J Biol Chem 2004;279(20):21085-95.

17. Sanderson TH, Kumar R, Sullivan JM, Krause GS. Insulin blocks cytochrome $\mathrm{c}$ release in the reperfused brain through PI3-K signaling and by promoting Bax/Bcl-XL binding. J Neurochem 2008;106(3):1248-58.

18. van der Heide LP, Ramakers GM, Smidt MP. Insulin signaling in the central nervous system: Learning to survive. Prog Neurobiol 2006;79(4):205-21.

19. Cervellati C, Romani A, Seripa D, Cremonini E, Bosi C, Magon S, et al. Oxidative balance, homocysteine, and uric acid levels in older patients with late onset Alzheimer's disease or vascular dementia. J Neurol Sci 2014;337(1-2):156-61.

20. Nunomura A, Perry G, Aliev G, Hirai K, Takeda A, Balraj EK, et al. Oxidative damage is the earliest event in Alzheimer disease. J Neuropathol Exp Neurol 2001;60(8):759-67.

21. Valko M, Leibfritz D, Moncol J, Cronin MT, Mazur M, Telser J. Free radicals and antioxidants in normal physiological functions and human disease. Int J Biochem Cell Biol 2007;39(1):44-84.

22. Ambati RR, Phang SM, Ravi S, Aswathanarayana RG. Astaxanthin: Sources, extraction, stability, biological activities and its commercial applications - A review. Mar Drugs 2014;12(1):128-52.

23. Fassett RG, Coombes JS. Astaxanthin: A potential therapeutic agent in cardiovascular disease. Mar Drugs 2011;9(3):447-65.

24. Pashkow FJ, Watumull DG, Campbell CL. Astaxanthin: A novel potential treatment for oxidative stress and inflammation in cardiovascular disease. Am J Cardiol 2008;101(10A):58D-68.

25. Stanier RY, Kunisawa R, Mandel M, Cohen-Bazire G. Purification and properties of unicellular blue-green algae (order Chroococcales). Bacteriol Rev 1971;35(2):171-205.

26. Liang H, He J, Ma AG, Zhang PH, Bi SL, Shi DY. Effect of ethanol extract of alga Laurencia supplementation on DNA oxidation and alkylation damage in mice. Asia Pac J Clin Nutr 2007;16 Suppl 1:164-8.

27. Kumar V, Bal A, Gill KD. Aluminium-induced oxidative DNA damage recognition and cell-cycle disruption in different regions of rat brain. Toxicology 2009;264(3):137-44.
28. Tifratene K, Duff FL, Pradier C, Quetel J, Lafay P, Schück S, et al. Use of drug treatments for Alzheimer's disease in France: A study on a national level based on the National Alzheimer's Data Bank (Banque Nationale Alzheimer). Pharmacoepidemiol Drug Saf 2012;21(9):1005-12.

29. El-Baz FK, Khalil WK, Booles HF, Aly HF, Ali GH. Dunaliella salina suppress oxidative stress, alterations in the expression of pro-apoptosis and inflammation related genes induced by STZ in diabetic rats. Int J Pharm Sci Rev Res 2016;38(2):219-26.

30. Tsakiris S, Schulpis KH, Marinou K, Behrakis P. Protective effect of L-cysteine and glutathione on the modulated suckling rat brain $\mathrm{Na}^{+}$, $\mathrm{K}^{+}$, - ATPase and $\mathrm{Mg} 2^{+}$-ATPase activities induced by the in vitro galactosaemia. Pharmacol Res 2004;49(5):475-9.

31. Moron MS, Depierre JW, Mannervik B. Level of glutathione, glutathione reductase and glutathione S-transferase activities in rat lung and liver. Biochim Biophys Acta 19795;582(1):67-78.

32. Ozdemir G, Ozden M, Maral H, Kuskay S, Cetinalp P, Tarkun I. Malondialdehyde, glutathione, glutathione peroxidase and homocysteine levels in Type 2 diabetic patients with and without microalbuminuria. Ann Clin Biochem 2005;42:99-104.

33. Satoh K. Serum lipid peroxide in cerebrovascular disorders determined by a new colorimetric method. Clin Chim Acta 1978;90(1):37-43.

34. Barbareschi M, Caffo O, Veronese S, Leek RD, Fina P, Fox S, et al. Bcl-2 and p53 expression in node-negative breast carcinoma: A study with long-term follow-up. Hum Pathol 1996;27(11):1149-55.

35. Barakat-Walter I. Brain-derived neurotrophic factor-like immunoreactivity is localized mainly in small sensory neurons of rat dorsal root ganglia. J Neurosci Methods 1996;68(2):281-8.

36. Villalba M, Martínez-Serrano A, Börner C, Blanco P, Satrústegui J. NMDA-induced increase in $[\mathrm{Ca} 2+] \mathrm{i}$ and $45 \mathrm{Ca} 2+$ uptake in acutely dissociated brain cells derived from adult rats. Brain Res 1992;570(1-2):347-53.

37. Khalil WK, Booles HF. Protective role of selenium against overexpression of cancer-related apoptotic genes induced by o-cresol in rats. Arh Hig Rada Toksikol 2011;62(2):121-9.

38. El-Baz FK, Aly HF, Khalil WK, Booles HF, Saad SA. Jatropha curcas repairing effect on adhesion molecules, DNA damage and gene expression alteration in STZ-induced diabetic rats. Int J Pharm Bio Sci 2015;6(3):(B)198-214.

39. Li H, Kang T, Qi B, Kong L, Jiao Y, Cao Y, et al. Neuroprotective effects of ginseng protein on PI3K/Akt signaling pathway in the hippocampus of D-galactose/ $\mathrm{AlCl} 3$ inducing rats model of Alzheimer's disease. J Ethnopharmacol 2016;179:162-9.

40. Navarro A, Boveris A. Brain mitochondrial dysfunction in aging, neurodegeneration, and Parkinson's disease. Front Aging Neurosc 2010;2. pii:34.

41. Salem AM, Sabry GM, Ahmed HH, Hussein HA, Kotob SE. Amelioration of neuroinflammation and apoptosis characterizing Alzheimer's disease by natural products. Int J Pharm Pharm Sci 2013;2(5):87-94.

42. Aly HF, Metwally FM, Ahmed HH. Neuroprotective effects of dehydroepiandrosterone (DHEA) in rat model of Alzheimer's disease. Acta Biochim Pol 2011;58(2):513-20.

43. Bathina S, Srinivas N, Das UN. BDNF protects pancreatic $\beta$ cells (RIN5F) against cytotoxic action of alloxan, streptozotocin, doxorubicin and benzo(a)pyrene in vitro. Metabolism 2016;65(5):667-84

44. Johnson VJ, Kim SH, Sharma RP. Aluminum-maltolate induces apoptosis and necrosis in neuro-2a cells: Potential role for p53 signaling. Toxicol Sci 2005;83(2):329-39.

45. Kalam S, Gul MZ, Singh R, Ankati S. Free radicals: Implications in etiology of chronic diseases and their amelioration through nutraceuticals. Pharmacologia 2015;6:11-20.

46. Polotow TG, Poppe SC, Vardaris CV, Ganini D, Guariroba M, Mattei R, et al. Redox status and neuro inflammation indexes in cerebellum and motor cortex of wistar rats supplemented with natural sources of omega-3 fatty acids and astaxanthin: Fish oil, krill oil, and algal biomass. Mar Drugs 2015;13(10):6117-37.

47. Aoi W, Naito Y, Takanami Y, Ishii T, Kawai Y, Akagiri S, et al. Astaxanthin improves muscle lipid metabolism in exercise via inhibitory effect of oxidative CPT I modification. Biochem Biophys Res Commun 2008;366(4):892-7.

48. Lobos P, Bruna B, Cordova A, Barattini P, Galáz JL, Adasme T, et al. Astaxanthin protects primary hippocampal neurons against noxious effects of Aß-oligomers. Neural Plast 2016;2016:3456783.

49. Wu H, Niu H, Shao A, Wu C, Dixon BJ, Zhang J, et al. Astaxanthin as a potential neuroprotective agent for neurological diseases. Mar Drugs 2015;13(9):5750-66.

50. Rege SD, Geetha T, Broderick TL, Babu JR. Resveratrol protects 
ß amyloid-induced oxidative damage and memory associated proteins in H19-7 hippocampal neuronal cells. Curr Alzheimer Res 2015;12:147-56.

51. Kim SH, Jean D, Lim YP, Lim C, An G. Weight gain limitation and liver protection by long-term feeding of astaxanthin in murines. J Korean Soc Appl Biol Chem 2009;52(2):180-5.

52. Bolin AP, Macedo RC, Marin DP, Barros MP, Otton R. Astaxanthin prevents in vitro auto-oxidative injury in human lymphocytes. Cell Biol
Toxicol 2010;26(5):457-67.

53. Liu X, Shibata T, Hisaka S, Osawa T. Astaxanthin inhibits reactive oxygen species-mediated cellular toxicity in dopaminergic SH-SY5Y cells via mitochondria-targeted protective mechanism. Brain Res 2009; 1254:18-27.

54. Park JS, Mathison BD, Hayek MG, Zhang J, Reinhart GA, Chew BP. Astaxanthin modulates age-associated mitochondrial dysfunction in healthy dogs. J Anim Sci 2013;91(1):268-75. 